deserving projects when the criteria of success are linked not with the promise of academic gain but, rather, with the promise of economic benefits of various kinds. One obvious difficulty is that the foundation will find itself having to encourage extremely speculative ventures. If the object, for example, is to improve the productivity of the electronics industry, there will be no point in looking for mechanical inventions which will actually improve the production process, for industry is likely to have thought of projects like that off its own bat. By the same token, the foundation is unlikely to find much scope for its activities in projects of the kind which the Government establishments at present carry out. But this, however, seems to be fully appreciated. The object is somehow to devise new ways in which universities at present too detached from the problems of the economy and industry can make useful contributions.

\section{Changes for Cambridge?}

THE University of Cambridge publishes this week its answer to the Franks Commission Report. In fact the comparison is unfair, because the committee under Dr W. W. Grave considered only the administrative functions of the university, and excluded consideration of admission procedures, the relationship between the university and the colleges, and the like, which took the Franks Commission so long to work out. Dr Grave, Master of Fitzwilliam, has taken only a year to produce the report, advised by a committee of three, Mr J. S. Boys-Smith, Sir Frank Lee and Lord Butler.

The report recommends a number of administrative adjustments. The Senate of the university, to which all holders of the MA belong, would give up some of its powers to the Regent House, the body representing the resident teaching and administrative members of the Senate. The Senate should retain only the power to elect the chancellor of the university and the high steward. The Regent House, which should consist of all teaching members of the university (and not only those already members of the Senate) should be responsible for electing the vicechancellor, conferring degrees, approving new courses leading to degrees, and deciding broad questions of building policy. At present, though, Regent House is often asked to determine detailed implementation of policy, and the report recommends that these detailed decisions be transferred to central bodies such as the Council of the Senate. The central bodies themselves should also be reorganized. At present there are three - the Council of the Senate, the General Board of the Faculties and the Financial Board; the report recommends that the Council of the Senate should become the supreme body, and that the other two should rank as committees of the Council. This change, the committee hopes, will reduce the continuous reference back that exists between the three administrative offices. The new council would consist of the chancellor, vicechancellor, two members from among the heads of colleges, two professors or readers and twelve members of the Regent House.

The report also seeks to make it harder for the Regent House to block new legislation. Requests for ballots should need at least twenty signatures, and proposals should not be rejected unless objectors are in a majority and number more than 100 . In proposing changes in the tenure of the vice-chancellorship, the committee has reached a compromise between the two year period now in operation and the four year term which the University of Oxford has adopted. Rather halfheartedly, it recommends a term of three years. The election of proctors should not be changed, but women should be eligible. The report also recommends, perhaps with the Prince of Wales in mind, that a press officer for the university should be appointed.

\section{.... and for Oxford \\ from our Oxford Correspondent}

THE University of Oxford is ringing in the academic year with some long awaited changes. For the past three terms Congregation, the assembly of the senior members of the university, has been debating fourteen new statutes reframing the administration of the university according to the proposals of the Franks Commission. The statutes have now been published, and will become effective subject to the formal approval of the Queen in Council. From 1969 onwards, the vicechancellor, who will no longer have to be the head of a college but only a senior member of the university, will be elected by Congregation on the nomination of a committee. Since 1957 the term of office of the vicechancellor has been fixed at two years, a period too short for him to do much more than learn his duties, which include the chairmanship of all the more important committees of the university and the representation of the university to outside bodies. Under the new statutes vice-chancellors will remain in office for four years; the term of the present vice-chancellor will be extended until the election of his successor. The Hebdomadal Council, whose functions are comparable with those of a government cabinet, is to be made formally responsible for the administration of the university, and the administrative services which execute its decisions are to be unified under the registrar.

The new statutes differ from the proposals of the Franks Commission over the question of the composition of the General Board, the concern of which is with matters academic rather than administrative. At present the board consists of the vice-chancellor, certain other university officials, and one representative from each of the sixteen faculties. The Franks Commission had proposed that there be only five faculties, each with two members of the board, and that many of the present faculties be reduced to sub-faculties. A year ago, Congregation approved the scheme in principle, by 114 votes to 112 . The Hebdomadal Council and the General Board itself, however, opposed the proposal "because it seemed to them that the new faculty boards would have no clear function to perform, and that the new sub-faculty boards (up to forty in number) would fragment academic administration too greatly". Congregation was therefore advised to reject the statute, and the constitution of the General Board will remain the same, with the important 
exception that no longer will all the faculties be represented. Instead, six board members will be chosen by Congregation from the nine arts faculties, and six from the seven scientific faculties.

\section{No Swan Song Yet}

To read the annual report of the Atomic Energy Authority is to forget that the organization is going through a crisis. There is, it is true, a little retrospective nostalgia about the early days at Calder Hall, now ten years away, but the report barely mentions the reduction in expenditure at Culham, or Lord Penney's imminent retirement and the urgent need for a successor. The report gives the impression that the authority will go on for ever, occasionally annexing new fields of research, but basically unchanged. Perhaps it will, but to outsiders this is beginning to look increasingly unlikely.

It has been another year of success for the authority, although expenditure on nuclear research and development was held at the $1965-6$ figure of $£ 38 \cdot 5$ million. Capital expenditure in this area did increase, from $£ 8.5$ to $\mathfrak{1 1}$ million, and research expenditure in nonnuclear fields was up to $£ 772,000$, most of it spent on desalination. The trading fund, which covers sale of isotopes, electricity and nuclear fuel services, made a

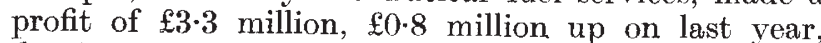
despite a 25 per cent reduction in the sale of fuel because of the reduced requirements of the Central Electricity Generating Board for initial charging for new magnox stations. The resources of the trading fund are to be used to pay for the re-activation of the Capenhurst fuel enrichment factory. The changes at Capenhurst, the report reveals, involve the complete reconstruction of the larger process units of the plant, and the enlarged factory will supply enriched uranium for the first three advanced gas cooled reactors, Dungeness $B$, Hinkley point $B$ and Hunterston $B$.

The expenditure of the authority has declined this year, from $\mathfrak{£ 7 8 . 8}$ million to $£ 71.5$ million, and receipts, which include payments from the Ministry of Tech-

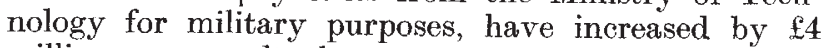
million; as a result, the net expenditure is given as $£ 17$ million against $£ 28$ million last year. The development of reactor systems has of course continued, and the prototype fast reactor at Dounreay made progress. Contracts have now been placed for about half the work on the station, and the fuel specifications will be completed soon. An improved sub-assembly has been examined in some detail, and design detail of other materials has continued. The steam generating heavy water reactor at Winfrith was completed, and confirmed that this type of reactor can be built comparatively quickly, because all the principal components can be shopfabricated.

\section{Getting round GATT}

MR WiLson's latest device for cutting the British import bill has been constructed with considerable tactical skill. GATT, the General Agreement on Tariffs and Trade, frowns on most easy ways of aiding the balance of payments-import surcharges, or direct subsidies to home producers-and import restrictions invite retaliation from other countries. The British Government is now proposing to establish a new indus- try in Britain by allowing aluminium companies to negotiate special prices for the electricity which they use to smelt aluminium. The smelters will pay the generating boards a sum equal to the capital cost of the power needed, and will then buy the electricity at near cost price. Because of the advantages of building big, and the fact that no smelting plant so far contemplated could use the entire output of a large station, it is likely that the aluminium companies would take a proportion of the output of a 1,200 MW nuclear station, perhaps as much as $300 \mathrm{MW}$. Electricity could then be supplied to the smelters at prices as low as $0.5 d$. a unit if they were prepared to build plants next door to power stations. Transmission costs would increase this slightly if the power station and smelting plant were not next door to each other.

The financial arrangements for the deal are confused. In addition to the low cost power, investment grants at the rate of 45 per cent will be given for the smelter. but the aluminium companies say that they will also need investment grants for their share of the capital cost of the power station if they are to compete with smelters in the USA, Labrador and Newfoundland, where power costs are around $0 \cdot 25 d$. per unit. The Ministry of Power has different ideas; it confirmed this week that investment grants would be available only for the smelting plant and not for the power station.

But if aluminium is to have these advantages, why should not other industries also jump on the bandwagon? This has been the perfectly understandable response from a number of industries. The Prime Minister made clear that the favourable terms would only be available in development areas and when the investment could be seen to aid the balance of payments. There is another important proviso, howcver: the arrangements will not be available to existing companies for existing operations. Only if they are prepared to sanction large expansion in their activities, or a completely new industry, and offer savings to the balance of payments ( $£ 30$ million is the estimate for the aluminium companies), would the arrangements be negotiable. In other words, existing businesses using large quantities of electricity will have to put up very convincing cases - and a huge investment, of the order of $£ 1$ million for every $10 \mathrm{MW}$ of powerbefore they are likely to get anywhere.

The bid by Imperial Chemical Industries for cheap power for chlorine manufacture maybe the best prospect outside the aluminium companies. Other possibilities include British Petroleum, with its new petrochemical interests, and possibly Courtaulds. The other processes which use electricity intensively-magnesium, sodium, potassium and calcium production, for instance, are probably not large cnough to justify special arrangements. The British Steel Corporation produces more than 3 million metric tons of steel annually by the electric furnace method-almost 14 per cent of the total output-but since production is already in progress. and expanding, it is unlikely that the BSC could legitimately claim cheap power, even as a means of achieving its cherished aim of cutting steel prices. The first plan, put up by Rio Tinto Zinc, is still the simplest: RTZ would share a 1,200 MW station with the Atomic Energy Authority. The AEA share of the power would be used to run the uranium enrichment plant at Capenhurst, expanded-hopefully-to supply uranium to the Common Market countries, if Britain gets in. 